\title{
Aesthetic rehabilitation through dentogingival prosthesis for patients with high smile line
}

Amanda Mahammad Mushashe ${ }^{\mathrm{a}}$, Leonardo Fernandes da Cunha ${ }^{\mathrm{b}}$, Carlos Eduardo Edwards Rezende ${ }^{\mathrm{b}}$, Carla Castiglia Gonzaga ${ }^{\mathrm{b}}$, Gisele Maria Correr ${ }^{\mathrm{b}}$

\section{ABSTRACT}

OBJECTIVE: This report aimed to present a case of functional and aesthetic rehabilitation of anterior maxillary region through dentogingival prosthesis in a patient with high smile line.

CASE DESCRIPTION: Patient female, 65 years old, had aesthetic complaints related to fixed partial denture from upper left canine to upper right lateral incisor. The patient reported loss of upper central incisors due to periodontal disease progression. Clinical and radiographic examination showed marginal leakage, discrepancy in teeth proportion, dental inclination and alignment, and excessive prolongation of the cervical-incisal direction, plus a resorbed alveolar ridge, in both volume and height, in the described area. Faced with these conditions, it was decided to perform a fixed partial dentogingival denture, restoring harmony and smile functionality.

CONCLUSION: After a 1-year follow up, maintenance of functional and aesthetic aspects of the prosthesis was observed

Keywords: dental esthetics; fixed partial denture; mouth rehabilitation.

\section{Reabilitação estética através de prótese dentogengival em paciente com linha alta de sorriso}

\section{RESUMO}

OBJETIVO: O objetivo deste trabalho é relatar um caso de reabilitação estética e funcional da região ânterosuperior, através de prótese dentogengival em uma paciente com linha alta de sorriso.

RELATO DE CASO: Paciente feminina, 65 anos, apresentou queixa estética relacionada à prótese parcial fixa do canino superior esquerdo ao incisivo lateral superior. A paciente relatou a perda dos incisivos centrais superiores devido à progressão de doença periodontal. Através de avaliação clínica e radiográfica observou-se na área descrita: infiltração marginal das restaurações, discrepância na proporção, inclinação e alinhamento interdentários, relacionados à rebordo alveolar reabosrvido, tanto em volume como em altura. Nestas condições, optou-se por realizar uma prótese parcial fixa dentogengival, restaurando a harmonia e a funcionalidade do sorriso.

CONCLUSÃO: Após um ano de acompanhamento, foi observado manutenção dos aspectos funcionais e estéticos da prótese.

Palavras-chave: estética dental; prótese parcial fixa; reabilitação bucal. a PhD student of the Graduate Program in Dentistry, Operative Dentistry Area, Universidade Positivo, Curitiba, PR, Brazil

b Professor of the Graduate Program in Dentistry, Operative Dentistry Area, Universidade Positivo, Curitiba, PR, Brazil

Conflict of Interests: The authors state that there re no financial and personal conflicts of interest that could have inappropriately influenced their work.

Copyright: (c) 2017 Mushashe et al licensee EDIPUCRS. 


\section{INTRODUCTION}

The aesthetic enhancement is one of the most frequent reasons for patients to seek prosthetic rehabilitation of the smile, especially when discrepancies are found in maxilloanterior region $[1,2]$.

The harmony and uniformity required are achieved when there is a correct relationship between dental and gingival components, and those with the individual facial patterns $[1,3]$. Thus, characteristics such as: tooth shape and size, interdental proportion, gingival contour, presence of interdental papillae, among others, are essential elements to be evaluated during an aesthetic analysis [4].

Changes in the teeth proportionality and their relationship with the adjacent gingival tissue in maxillary regions are common in cases of bone loss, mainly due to trauma, dental extractions and severe periodontal diseases [5]. In rehabilitation through fixed prostheses supported by teeth or implants, the bone resorption in this area complicates the functional and aesthetic reestablishment. In order to compensate the bone defect, the prosthesis in these regions tend to present an artificial emergence profile, extended cervical-incisal dimension, teeth with rectangular anatomy, long contact surfaces and labial inclination, changing the lip support homogeneity [5].

In an attempt to minimize the aesthetic effects of bone resorption in the anterior region, the prosthetic rehabilitation planning may involve the use of dentogingival prosthesis [7]. Through constant improvement of materials and techniques, these restorations allow the simultaneous reestablishment of dental and gingival characteristics, favoring a harmonious relationship between them. In addition to the micro-aesthetics, dentogingival prostheses, compared with conventional surgical-prosthetic rehabilitation, have advantages such as simplified and shorter treatment, correction of maxillofacial defects, compensation of inadequate maxillo-mandibular relations, air sealing for phonetic optimization, among others $[6,7]$.

Therefore, this report aimed to present a functional and aesthetic rehabilitation of maxillo-anterior region, through dentogingival prosthesis, in a patient with a high smile line.

\section{CASE DESCRIPTION}

Female patient, I.M., 65 years, sought a private dental clinic in Curitiba, Paraná, Brazil, with aesthetic complaint in relation to the size of constituent elements of a dental fixed partial prosthesis, comprised by the upper left lateral incisor to the upper left canine (Figure 1). The patient reported to have lost the upper central incisors 15 years ago, due to periodontal disease.

After clinical and radiographic examination, there was no proportion between anterior elements, with extended cervical-incisal dimension and misshapen corresponding gingival contour (Figure 2). In addition to the discrepancy in size and shape, the upper left lateral incisor had a composite of resin repair, with stained and infiltrated margins. Superiorposterior elements had implant-tooth-supported prosthesis, with exposure of margins.

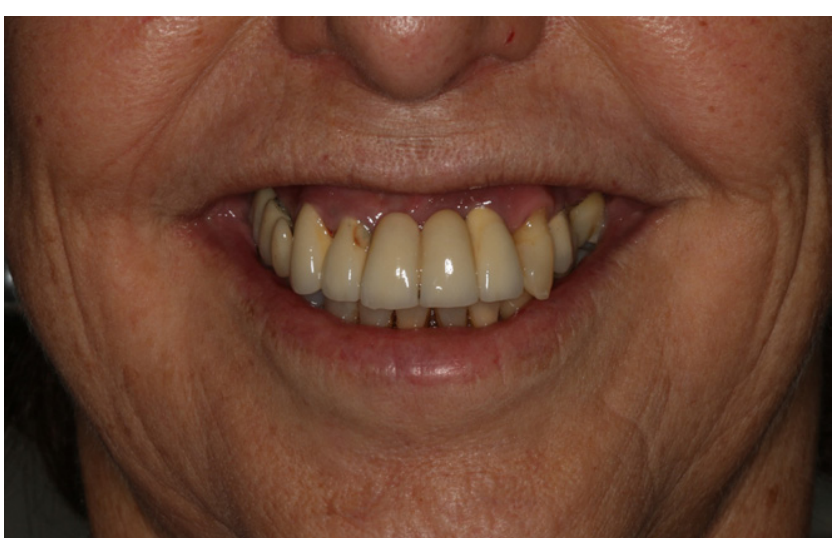

Figure 1. Frontal view of the smile, presenting discrepancy in the tooth proportions and in its correlation to the adjacent gingival tissue.

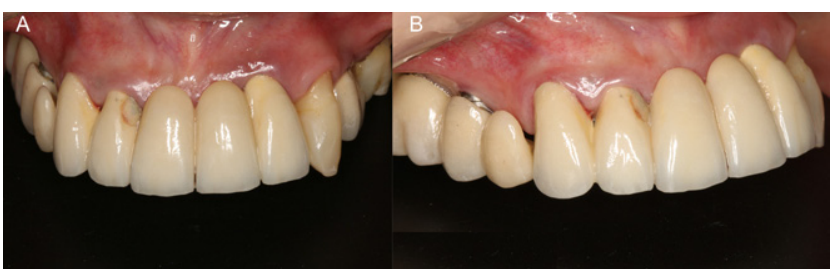

Figure 2. Close-up of frontal(A) and lateral(B) views. Angulation, shape and size discrepancies can be observed, in addition to the microleakage of prosthesis margins

Study models were obtained from the impression of both arches in alginate (Cavex Color change ${ }^{\circledR}$, Cavex Holland BV, Haarlem, The Netherlands), allowing the preparation of the diagnostic waxing. After removing the previous prosthesis, by means of diamond burs, a slight degree of gingival inflammation was observed around the abutment tooth, in addition to an alveolar bone reabsorption in the region of the central upper incisors determined as defective Class III, according to the Siebert rating [2]. With the aid of waxing guides, provisional prosthesis of bisacrylic resin (Protemp $4^{\circledR}, 3 \mathrm{M}$ ESPE, Minnesota, USA) were produced and installed.

Further, the upper lateral incisors and the upper left canine, determined as abutments, were reprepared through diamond burs, presenting chamfer end and reduction of around $1.5 \mathrm{~mm}$ in axial walls and $2 \mathrm{~mm}$ in incisal faces. Complementing the anterior aesthetic rehabilitation, the upper right canine was prepared for an all-ceramic crown, with the same characteristics used for fixed prosthesis pillars.

Regarding the maxillary posterior teeth, the abutments on the tooth were reprepared, following the biomechanical principles, for the preparation of new implant-toothsupported prostheses. 
Following the pattern set by waxing, a dentogingival prosthesis in acrylic resin was made in the laboratory and installed after abutment teeth preparation. This provisional prosthesis was used for a period of two weeks, in order to enable evaluation of functional and aesthetic patterns and provide the gingival tissue conditioning (Figure 3).

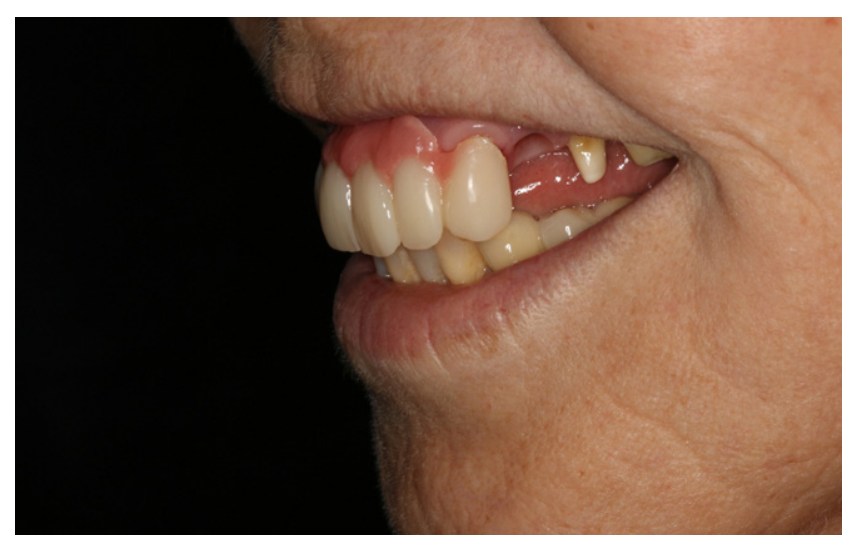

Figure 3. Lateral view of the provisional dentogingival prosthesis installed, already promoting restoration of tooth proportion and gingival conditioning.

For the impression procedure, gingival retraction was achieved with double-wire technique and the impression was performed in a single step by the technique of double mixing, using polyvinyl siloxane (Express $\mathrm{XT}^{\mathbb{B}}, 3 \mathrm{M}$ ESPE). In the laboratory environment, working models were mounted on articulator in maximum intercuspation position, using the inter-occlusal records clinically obtained by occlusion registration silicone (O-Bite ${ }^{\circledR}$, DMG ChemischPharmazeutische, Hamburg, Germany).

On the working model, a metal infrastructure was made of a CoCr alloy, by the lost wax technique. After the framework proof, the ceramic system (Alliance ${ }^{\circledR}$, Noritake Dental Supply, Nagoya, Japan) was pressed onto the framework. It was considered the masking of interfaces between natural and artificial gingiva, determining that the horizontal line should stay above the smile line and the vertical lateralized in relation to the front view. Teeth and gums colors were determined, respectively, through specific scales (Vita 3D ${ }^{\circledR}$ Master and Vita VMK Master ${ }^{\mathbb{B}}$ Gingiva, VITA Zahnfabrik, Bad Säckingen, Germany).

After proof and initial occlusal adjustment, the prosthesis was polished and cemented using the dual resin cement (Rely X Ultimate ${ }^{\circledR}, 3 \mathrm{M} \mathrm{ESPE}$ ) (Figures 4 to 6). The patient was oriented about the prosthesis maintenance and received oral and written instructions about oral hygiene. The patient follow up comprised the period of one year, in which normal aspects of the underlying gingival tissue were observed, as well as the maintenance of the prosthesis aesthetic and functional properties.

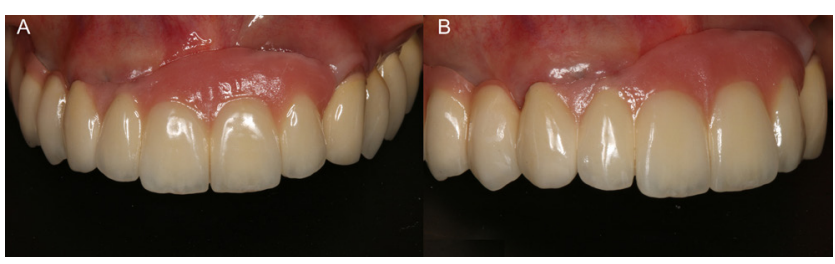

Figure 4. Close-up of the frontal $(A)$ and lateral $(B)$ views of the final dentogingival prosthesis

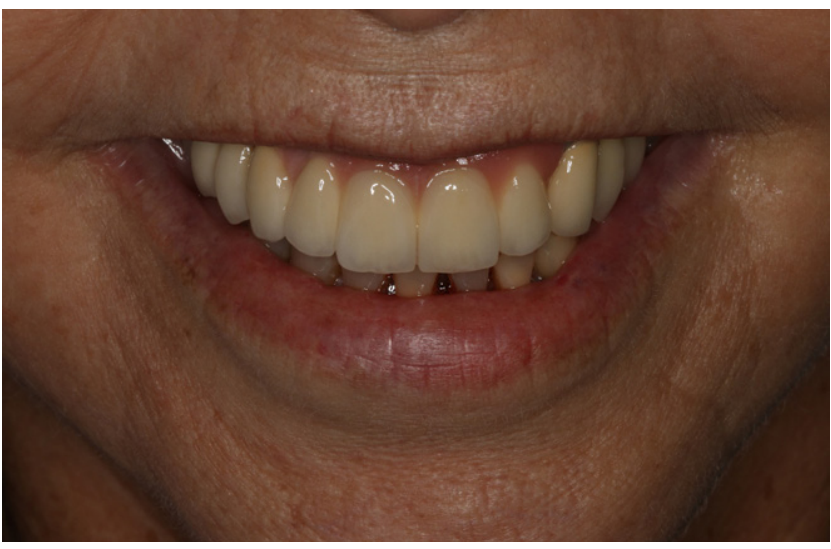

Figure 5. Final photos. The correct masking of the interface line between the artificial and natural gingiva can be seen, with a satisfactory coverage by the upper lip.

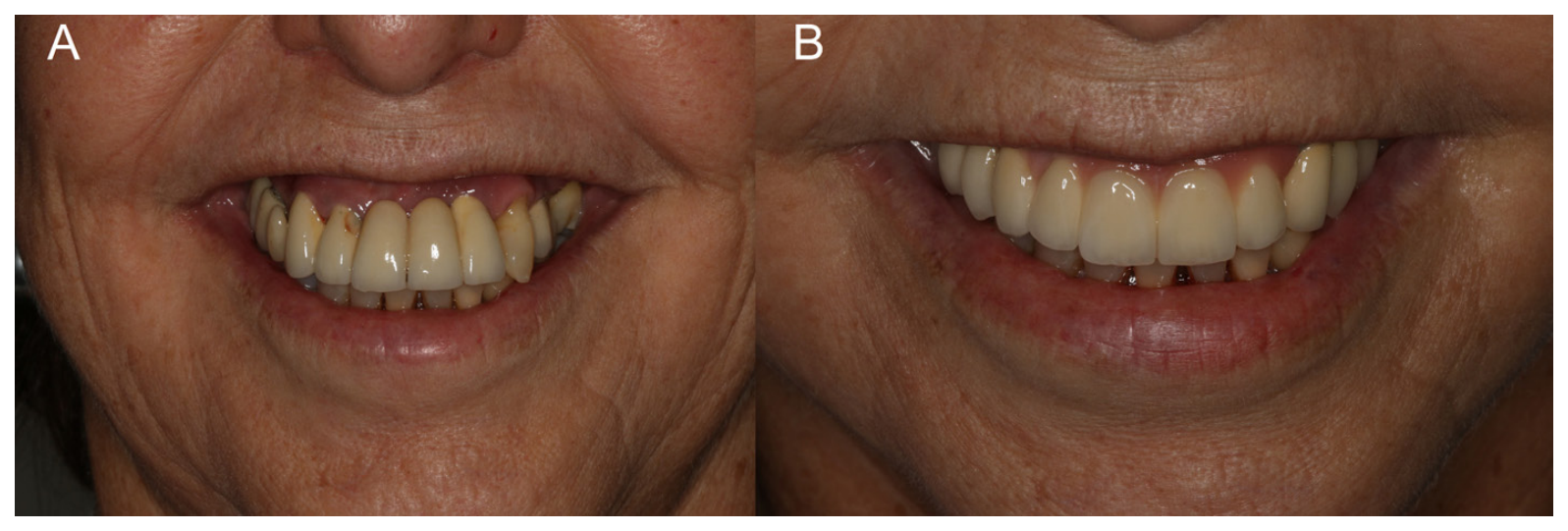

Figure 6. Comparison of the initial (A) and final (B) photos. 
The patient provided written informed consent to publish this case report and the accompanying images.

\section{DISCUSSION}

The aesthetic reestablishment is one of the main objectives in dental rehabilitations [1]. The determination of a harmonious smile takes into account not only the dental components, but also their interrelation with the adjacent gingival tissues [2].

The aesthetic property becomes even more relevant in the rehabilitation of areas with extensive visual display, as is the case of anterior maxillofacial treatment in patients with high smile line [8]. Tooth loss in this region, derived from periodontal disease, caries, fractures, congenital defects, among others, tend to impair the aesthetic uniformity between the tooth and gingival elements, since they can lead to resorption of the alveolar ridge [5].

In this case report, the patient presented an anterior defect classified as Seibert Class III, determined by the loss of bone volume and height [2]. The alveolar ridge resorption in this region resulted from the non-treatment after tooth loss, complicating the establishment of fixed partial dentures (FPD) with satisfactory aesthetic patterns. In the initial aesthetic analysis, it was observed that the previous prosthesis had: dental stretching of the cervico-incisal direction, change of teeth shape and form, heterogeneity in the smile bow, teeth with a rectangular shape, long contact surfaces and diverging dental axes to occlusal plane. These elements were more evidenced because of the fact that the patient has a high smile line. Characteristics found in this case are consistent with other studies in the literature, which determine the disparate aesthetic aspects of FPDs that aim to compensate this bone defect $[1,6,7]$.

The treatment planning of anterior rehabilitation, involving tooth loss and bone defects, should take into account aspects such as: longevity and prognosis; hygiene and ease of maintenance; cost; patient's systemic conditions; aesthetic and functional analysis of facial and dental-gingival patterns; among others [8].

In order to reestablish the aesthetic and functional standards related to prosthetic rehabilitation of reabsorbed edentulous ridges, numerous treatment options are available and well documented in the literature [8]. In this case, exclusively dental rehabilitation, involving the use of removable or fixed partial dentures, would not allow the desired aesthetic reach because of the absence of harmony of the gingival contour. The red aesthetics could be obtained through a surgical approach of the periodontal tissues, involving the use of soft and hard grafts (autogenous or not) associated with implant loading maxillary distraction, among other techniques $[7,8]$.

However, some limitations related to these treatment options should be considered, such as: increased time and cost of treatment, increased patient morbidity, infection and graft contamination, etc.
The literature has proposed grafts of hard and soft tissues associated with implant therapy, in order to restore the alveolar ridge condition and allow the prosthetic rehabilitation [5]. However, some authors report that these procedures have an uncertain prognosis. Chiapasco et al. [9], after evaluation of the clinical outcomes of fresh frozen human allogeneic bone grafts (FFB) used for the reconstruction of severely atrophied edentulous ridges of 19 patients, observed that in 13 cases occured graft exposure with partial or total loss of the graft occurred, prior or after implant placement.

Pjetursson et al. [10], reported that there were more technical complications related to implant-supported reconstructions in relation to those that are tooth-supported. Moreover, Ziztmann et al. [8], determined that both treatments show satisfactory results in the long term from the standpoint of the patient, and the relative lower cost leads to a greater preference of rehabilitation promoted by prosthetic implant.

In this case, treatment options were presented to the patient, whom considered herself systemically limited and reported emotional distress on the use of removable devices, excluding the possibility of any surgical intervention and determined rehabilitation with fixed partial dentogingival prosthesis. This type of prosthesis, in addition to promoting harmony and proportionality between dental and gingival components, allows the correction of maxillofacial defects, compensates inadequate maxillo-mandibular relations and provides air sealing during phonation [6].

One of the most important challenges in this case was masking the interface between the gingival and artificial tissue, since the patient had extensive exposure of teeth and gingiva during smile. Planning the lower visibility of this interface is essential for the desired aesthetic range. Such ideal is reached by determining a transition line above the smile line, allowing the upper lip to mask this interface. Similarly, a prosthetic gingival end beveled was chosen, in order to promote a better transition between the artificial and natural tissues. The aesthetic and functional reach obtained in this case was also obtained by means of the choice of the restorative materials. The ceramic systems, in comparison to composites, have better optical characteristics of brightness, translucency and color stratification, maintaining such properties for a longer time in relation to indirect resins. Likewise, the structural rigidity and mechanical strength of the combination of the ceramic-infra-structure system of $\mathrm{CoCr}$ provides to the prosthesis an adequate resistance to functional stress.

The patient received oral and written information regarding the maintenance of the prosthesis, which involved the importance of oral hygiene and the attendance to periodic dental appointments. The establishment of a correct oral hygiene instruction is essential for the preservation of periodontal and dental tissues, avoiding the progression of gingival inflammation and/or secondary caries that may compromise the cervical sealing of the pillars tooth. 
Likewise, the proservation of the treatment through periodic dental appointments is important to diagnose early problems that may impair the maintenance of the prosthesis, such as cracks, small infiltrations, occlusal alterations, among others.

After one year of follow up, there was maintenance of the aesthetic and functional aspects of the dentogingival prosthesis, as well as the underlying tissue. The patient reported satisfaction with the aesthetic range achieved, agreeing with her initial desire and determining treatment success.

\section{CONCLUSION}

According to the purpose of this report, it could be concluded that, from an aesthetic point of view, the dentogingival prosthesis is an important treatment option in cases of previous bone defects associated with tooth loss in patients with high line smile.

\section{REFERENCES}

1. Hasanreisoglu U, Berksun S, Aras K, Arslan I. An analysis of maxillary anterior teeth: Facial and dental proportions. J Prosthet Dent 2005; 94:530-38. https://doi.org/10.1016/j.prosdent.2005.10.007

2. Seibert JS. Reconstruction of deformed, partially edentulous ridges, using full thickness onlay grafts. Part I. Technique and wound healing. Compend Contin Educ Dent 1983;4:43753.
3. Park BW, Kim NJ, Lee J, Lee HH. Technique for fabricating individualized dentures with a gingiva-shade composite resin. J Prosthet Dent 2016; 115(5):547-50. https://doi.org/10.1016/i.prosdent.2015.11.010

4. Rotundo R, Nieri M, Bonaccini D, Mori M, Lamberti E, Massironi D, Giachetti L, Franchi L, Venezia P, Cavalcanti R, Bondi E, Farneti M, Pinchi V, Buti J. The Smile Esthetic Index (SEI): A method to measure the esthetics of the smile. An intra-rater and inter-rater agreement study. Eur J Ora Implantol 2015:8(4):397-403.

5. Oh SC; Cha DH; Lee Jl. Combined application of roll flap and combination onlay-interpositional graft to enhance esthetics of maxillary anterior fixed partial denture: A case report. J Adv Prosthodont 2016;8:70-4. https://doi. org/10.4047/jap.2016.8.1.70

6. Coachman C, Salama M, Garber D, Calamita M, Salama H, Cabral G. Prosthetic gingival reconstruction in fixed partial restorations. Part 3 : laboratory procedures and maintenance. Int J Periodontics Restorative Dent 2010;30(1):19-29.

7. Sadaqah NR, Tair JA. Prosthetic reconstruction using gingiva-colored ceramic agent in fixed partial restoration in a 24-year old patient. Clin Cosmet Investig Dent 2012;30(4):37-41. https://doi.org/10.2147/CCIDE. S36273

8. Zitzmann NU, Krastl G, Weiger R, Kühl S, Sendi P. Cost-effectiveness of Anterior Implants versus Fixed Dental Prostheses. J Dent Res 2013;92(12):183S-8S. https://doi.org/10.1177/0022034513504927

9. Chiapasco M, Colletti G, Coggiola A, Di Martino G, Anello T, Romeo E. Clinical outcome of the use of fresh frozen allogeneic bone grafts for the reconstruction of severely resorbed alveolar $\mathrm{rs}$ : preliminary results of a prospective study. Int J Oral Maxillofac Implants 2015;30(2):450-60. https://doi.org/10.11607/jomi.3763

10. Pjetursson BE, Zwahlen M, Lang NP. Quality of reporting of clinical studies to assess and compare performance of implantsupported restorations. J Clin Periodon 2012;39(12):139-59. https://doi.org/10.1111/j.1600051X.2011.01828x

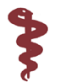

